JPH: Jurnal Pembaharuan Hukum

Volume 8, Number 3, December 2021

\title{
THE CONSTRUCTION OF TERRORISM PREVENTION IN LEGAL POLITICS
}

\author{
Bahtiyar Efendi \\ Universitas Nahdlatul Ulama Cirebon \\ tiyar3efendi@gmail.com
}

\begin{abstract}
Terrorism is a criminal act or extraordinary crime that is of concern to the world today, especially in Indonesia. Terrorism that has occurred in Indonesia recently has ideological, historical and political linkages and is part of the dynamics of the strategic environment at the global and regional levels. the approach method uses normative juridical, the results of the study state that the legal politics of eradicating criminal acts of terrorism in Indonesia is a proactive policy and anticipatory step that is based on prudence and is longterm in nature. The use of Act No. 15 of 2003 to regulate the eradication of criminal acts of terrorism is based on the consideration that the occurrence of terrorism in various places has caused material and immaterial losses and caused insecurity for the community. It can be stated that the government's policy to tackle criminal acts of terrorism is by taking legal steps, so that unwanted things can be anticipated.
\end{abstract}

Keywords : Construction; Legal; Politics; Terrorism.

\section{A. INTRODUCTION}

The Unitary State of the Republic of Indonesia is a legal state based on Pancasila and the 1945 Constitution. Laws made or created of course have goals to be achieved. That is the purpose of the law, which is essentially to create an orderly, safe, peaceful society and a balance in social life. With the achievement of order in society, it is hoped that human interests (legal subjects) will be protected without colliding with the interests of others. Therefore, the law must be tasked with dividing human rights and interests, dividing authority, and regulating how to solve/resolve if there are problems in defending their rights and obligations. ${ }^{1}$

In realizing an orderly, safe, and balanced society in the life of the people of the State, in this case, it has a big role, where we can see the goals and functions of the State, namely the maintenance of peace, order, security, and justice. If the State cannot fulfill that goal, then the existence of the State cannot be justified. In order to achieve the goals and functions of the State in society without colliding with the interests of others, the State must pay attention to aspects of law enforcement. ${ }^{2}$

Currently the Indonesian nation is entering a period towards the 4.0 era where investment is needed to support development in all fields.

1 Zaenai Asyhadie \& Arief Rahman, Pengantar Ilmu Hukum, Raja Grafindo Persada, Jakarta, 2013, page.116

2 Romi libriyanto, IImu Negara Suatu Pengantar, Arus timur, Makassar, 2013, page.124 
However, for the sake of increasing development in the framework of development, there is one thing that is certain, that the state must be able to provide security guarantees and legal certainty in law enforcement and security, especially regarding terrorism.

Terrorism is a criminal act or extraordinary crime that is of concern to the world today, especially in Indonesia. Terrorism that has occurred in Indonesia recently has ideological, historical and political linkages and is part of the dynamics of the strategic environment at the global and regional levels. Although acts of terrorism that have occurred in various regions in recent years are mostly carried out by Indonesians and only a few actors from outside. However, it cannot be denied that the current act of terrorism is a combination of domestic actors and those who have transnational networks. ${ }^{3}$

In order to prevent and combat terrorism, since long before the widespread occurrence of incidents classified as forms of terrorism occurring in the world, the international and regional communities as well as various countries have tried to carry out criminal policies accompanied by systematic and comprehensive criminalization of acts that are categorized as Terrorism. ${ }^{4}$

The virus of terrorism is nothing new in this country Indonesia is a country that does not escape the enactment and enactment of the Law on terrorism, namely the Act No. 15 of 2003 concerning the Stipulation of Government Regulations in Lieu of Act No. 1 of 2002 concerning the Eradication of Criminal Acts of Terrorism. ${ }^{5}$

Internet media is known as a very powerful tool for terrorist organizations. Prior to 1999, nearly 30 terrorist groups were discovered on the Internet by the United States Department of Government. However, the role of the Internet is even stronger for them when after the events of 9/11, the leadership of Al-Qaeda tried to spread videos from their hiding in Pakistan through Al-Jazeera television, but they were frustrated with their very small segment so that the message could be misperceived which then makes them turn to the Internet to upload it more clearly and in detail without any editing. ${ }^{6}$

Seeing the phenomenon of terrorist organizations that are increasingly systematic in recruiting and conducting regeneration, the government views an integrated and strategic effort to respond to this. This was responded to by the DPR, through a Working Meeting between Commission 1 of the DPR RI and the coordinating Minister for Political, Legal and Security Affairs (Menkopolhukam), on August 31, 2009. The DPR RI

3 Muhammad A.S. Hikam, Deradikalisasi: Peran Masyarakat Sipil Indonesia Membendung Radikalisme, PT Kompas Media Nusantara, Jakarta, 2016, page. 33-34.

4 Muladi, Hakekat Terorisme \& Beberapa Prinsip Pengaturan dalam Kriminalisasi, Jurnal Kriminologi Indonesia FISIP UI, Vol II No. 03 December 2002, page.1

5 Rifki Efendy, Kedudukan \& Kewenangan Tentara Nasional Indonesia Dalam Pemberantasan Terorisme Di Indonesia, Lex Crimen, Vol. III No. 1 Jan-Mar 2014, page.22-30

6 Eska Nia Sarinastiti \& Nabilla Kusuma Vardhani , Internet \& Terorisme: Menguatnya Aksi Global Cyber-Terrorism Melalui New Media, Jurnal Gama Societa, Vol. 1 No. 1, January 2018, page.40-52. 
through Commission 1 stated that it supports the government's efforts in tackling and eradicating the government, and recommends several points which were later embodied in the establishment of the National CounterTerrorism Agency (BNPT). The establishment of this institution is based on Presidential Regulation Number 46 of 2010 concerning the National CounterTerrorism Agency (BNPT). The establishment of BNPT marks the start of a new chapter in counter-terrorism methods that prioritize the soft approach method. The basis is law enforcement, where terrorism is considered a criminal act that falls into the category of extraordinary crimes. In efforts to counter terrorism, BNPT emphasizes integrative and comprehensive efforts, promoting a persuasive approach with various programs that touch the root of the problem, namely ideology, social, economic and injustice. In implementing its program, BNPT involves all components of the nation, both the government and the community. It is in this position that BNPT becomes the leading sector that coordinates all the potential power of various elements of the nation in countering terrorism. BNPT has the authority to formulate and make policies and strategies and become the coordinator in the field of terrorism prevention. Policy directions for the implementation of radical terrorism prevention must be effective, efficient, measurable, consistent, integrated, institutionalized, and sustainable. This policy direction includes preventing the spread of ideology and radical terrorism groups through socialization, prevention intelligence and training facilitation. This must also be in line with increasing public support for the movement against thought and action.

The purpose of this study is to analyze the growing terrorism prevention policy. The problem of handling terrorism in Indonesia is caused by the political stagnation of the law of terrorism which is still using the traditional law enforcement paradigm. So it needs to be harmonized based on that legal politics must be based on the four principles contained in the Fourth Paragraph of the Preamble to the 1945 Constitution of the Unitary State of the Republic of Indonesia. However, with the lack of development of legal policies related to the handling of theorists, this is inversely proportional to the progress of the modus operandi of criminal acts of terrorism. Along with advances in information and communication technology, this has resulted in ineffective handling of criminal acts of terrorism.

\section{B. RESEARCH METHODS}

The approach method used in this study uses a normative juridical approach, normative juridical research is a legal research that puts the law as a building system of norms. The system of norms in question is about principles, norms, rules of laws and regulations, agreements and doctrines (teachings). This research was conducted on secondary data such as legislation, scientific journals, legal books. ${ }^{7}$

7 Mukti Fajar, Yulianto Achmad, Dualisme Penelitian Hukum Normatif \& Empiris, , Pustaka Pelajar,Yogyakarta, 2010, page. 34. 


\section{RESULT AND DISCUSSION}

\section{Construction of Terrorism Prevention in Legal Politics}

Legal politics is a choice of laws to be repealed or not enforced, all of which are intended to achieve state goals as stated in the Preamble to the 1945 Constitution of the Republic of Indonesia. Moh. Mahfud MD provides a definition of legal politics as a legal policy or official line (policy) on the law that will be enforced, either by making new laws or by replacing old laws in order to achieve state goals. ${ }^{8}$

The term legal politics means agreeing that law cannot be separated from political aspects, even ideological, social, economic and so on. ${ }^{9}$ A new legal policy containing legal reform has become a necessity for Indonesia as an independent country since it was proclaimed in order to realize the ideals and goals of the Indonesian state. $^{10}$

The words "terrorist" and terrorism come from the Latin word "terrere" which more or less means to make a tremor or to shake. The word terror can also cause horror. ${ }^{11}$ Many opinions try to define terrorism, one of which is the definition contained in Article 14 paragraph (1) The Prevention of Terrorism (Temporary Provisions) act, 1984, as : "Terrorism means the use of violence for political ends and includes any use of violence for the purpose putting the public or any section of the public in fear". ${ }^{12}$

Terrorist activities have the aim of making other people feel afraid, so that they can attract the attention of people, groups or a nation. Usually acts of terror are used when there is no other way to carry out their will. Terrorism is used as a psychological weapon to create an atmosphere of panic, uncertainty and create public distrust of the government's ability and to force certain people or groups to obey the will of terrorists. ${ }^{13}$

The definition of a criminal act of terrorism according to Article 1 point 1 of Act No. 15 of 2003 is: "An act that fulfills the elements of a criminal act in accordance with the provisions of the law".

According to T. P. Thornton that terrorism is defined as the use of terror as a symbolic act designed to influence political policy and behavior in extra-normal ways, in particular by the use of violence and threats of violence. ${ }^{14}$

8 Moh. Mahfud MD, Politik Hukum di Indonesia, Third Printing, Revision Edition, Raja Grafindo Persada, Jakarta, 2010, page. 1.

9 Syahriza Alkohir Anggoro, Politik Hukum: Mencari Sejumlah Penjelasan, Jurnal Cakrawala Hukum, Volume 10 No. 1 June 2019, page.77-86

10 Derita Prapti Rahayu, Aktualisasi Pancasila Sebagai Landasan Politik Hukum Indonesia, Yustisia, Vol. 4 No. 1 January-April 2015, page.190-202

11 Abdul Wahid, Kejahatan Terorisme Prespektif Agama, HAM \& Hukum, Refika Aditama, Bandung, 2004, page. 22.

12 Loebby Loqman, Analisis Hukum \& Perundang-Undangan Kejahatan Terhadap Keamanan Negara di Indonesia, Universitas Indonesia, Jakarta, 1990, page. 98.

13 Ibid.

14 Muchamad Ali Syafaat, Terorisme, Definisi, Aksi \& Regulasi, Imparsial, Jakarta, 2003, page. 59. 
Terrorism can be interpreted as the use or threat of the use of physical violence that is planned, prepared and carried out suddenly against direct targets, which are usually non-combatants to achieve a political goal. The definition of terrorism by James Adams is: $:^{15}$ The use or threat of physical violence by individuals or groups for political purposes, either for the benefit of or against existing power, if the acts of terrorism are intended to shock, paralyze or intimidate a larger target group than its direct victims. Terrorism involves groups seeking to overthrow certain regimes to correct group/national grievances, or to undermine the existing international political order.

According to Paul Wilkinson, the notion of terrorism is an act of terror that is systematic, neat and carried out by a particular organization. ${ }^{16}$ The process of terror, according to E. V. Walter has 3 (three) elements, namely: ${ }^{17}$

a. Acts or threats of violence;

b. Emotional reaction to extreme fear on the part of the victim or potential victim;

c. Social impact following violence or threats of violence and the fear that follows.

Terrorism according to the Terrorism Act 2000 that terrorism has the meaning as the use or threat of action, with the characteristics of: ${ }^{18}$

a. Actions that involve serious violence against a person, serious damage to property, endanger the life of a person, not the life of the person carrying out the act, create a serious risk to public health or safety or for certain that are seriously designed to interfere or disrupt the system electronic;

b. The use or threat is designed to influence the government or to intimidate the public or certain sections of the public;

c. The use or threat is made for political, religious, or ideological purposes;

d. Subsection use or threats involving firearms and explosives.

Terrorism according to the United Nations Convention that is all forms of crime that is directed directly at the state with the intention of creating a form of terror against certain people or groups of people or the wider community. Whereas in the Indonesian Dictionary, terrorism is the use of violence or threats to demoralize, frighten and frighten, especially for political purposes. ${ }^{19}$

Terrorism is the common enemy of the Indonesian nation, the enemy of humanity, the enemy of the Indonesian people and the enemy

15 Simela Victor Mohamad, Terorisme \& Tata Dunia Baru, Pusat Pengkajian \& Pelayanan Informasi, Sekretariat Jendral DPR-RI, Jakarta, 2002, page. 106.

16 Abdul Wahid, op.cit., page. 29.

17 Muchamad Ali Syafaat, loc. cit, page.60

18 Abdul Wahid, op.cit., page. 29 \& 30.

19 Ibid. 
of the world. There are 2 (two) important reasons why terrorism has become a common enemy of the Indonesian people, namely: ${ }^{20}$

a. Democracy and political freedom are incomplete if you don't feel safe. Whereas the reform movement aims to make us all feel safer in our own homes and more comfortable in state life. We all take on the responsibility of fighting terrorism who want to take a sense of security;

b. Terrorism is a crime against humanity in the form of an organized movement. Today terrorism has a wide and global network that threatens national and international peace and security.

There are three main conventions related to terrorism in terms of eradicating criminal acts of terrorism, namely: ${ }^{21}$

a. International Convention and Suppression of Terorism 1937

b. International Convention For the Suppression of Terrorist Bombing 1997.

c. International Convention For the Suppression of Financing of Terorism 1999.

Between 2003 and 2005, a series of bombs continued to hit Indonesia, the largest of which was the J.W. hotel bombing. Marriot (August 2003), bombing in front of the Australian Embassy in Jakarta (September 2004) and Bali bombing 2 (October 2005). The series of terrorism crimes interrupts and destroys the inner atmosphere of the Indonesian people who have just enjoyed a more free and open sociopolitical life. Terror acts that occurred during the reformation era, according to the results of the research by the BNPT team, there were approximately 103 acts of terror that occurred, $41 \%$ of which were aimed at places of worship, especially churches and Christian institutions, $43 \%$ of the actions were directed to public places such as malls, restaurants, cafes, hotels, office buildings and markets, while the rest is intended for government offices and foreign offices such as embassies in Indonesia. Although the church became the target of high levels of terror in the reform era, several bombs were detonated at mosques, such as the Istiqlal Mosque, Jakarta in 1978 and 1999 and the Polresta mosque, Cirebon in 2011. ${ }^{22}$

Terror cases such as those that occurred in America and also in Indonesia, as well as experienced by many other countries around the world are still ongoing. After the WTC case, the number of terrors did not decrease, therefore experts believe terrorism is a form of backlash (blowback) on America's hegemony. Terrorism, according to Chalmers Johnson is the price and consequences that must be paid by the

20 Susilo Bambang Yudhoyono, Selamatkan Negeri Kita Dari Terorisme, Kementrian Koordinator Polkam, Jakarta, 2002, page. 4 \& 5.

21 Soeharto, Perlindungan Hak Tersangka, Terdakwa \& Korban Dalam Tindak Pidana Terorisme, Refika Aditama, Bandung, 2007, page. 3.

22 Agus SB, Darurat Terorisme, Kebijakan Pencegahan, Perlindungan \& Deradikalisasi, First Printing, Daulat Press, Jakarta, 2014, page. 15. 
"American Empire". Historical facts prove that there is a strong connection between Washington's involvement in international affairs and increased attacks on America. The term blowback was originally only used by circles within the American Intelligence Service (CIA) and began to spread throughout the world. Terrorism is a powerful weapon for those who have no power. People say terrorism is the power of the powerless. $^{23}$

Eradication of criminal acts of terrorism in Indonesia is a proactive policy and anticipatory step that is based on prudence and is long-term because:

a. The Indonesian community is a multi-ethnic society with diverse and inhabiting hundreds of thousands of islands scattered throughout the archipelago and some are located bordering other countries;

b. With the characteristics of the Indonesian people, all components of the Indonesian nation are obliged to maintain and increase vigilance in the face of all forms of activities which constitute international criminal acts of terrorism;

c. The conflicts that have occurred recently are very detrimental to the life of the nation and state and are a decline in civilization and can be used as a fertile ground for the development of criminal acts of international terrorism, both committed by Indonesian citizens and those committed by foreigners.

Eradication of criminal acts of terrorism in Indonesia is not merely a matter of law and law enforcement but is also a social, cultural, and economic problem that is closely related to the issue of national security so that policies and measures for prevention and eradication are also aimed at maintaining a balance in society. The obligation to protect the sovereignty of the state, the human rights of victims and witnesses, as well as the rights of the suspect/accused.

The Indonesian nation is a nation that upholds human civilization and has ideals of peace and longs for prosperity and has a strong commitment to maintaining the territorial integrity of the sovereign Unitary State of the Republic of Indonesia in the midst of the ups and downs of world peace and security.

A week after the first Bali Bombing tragedy in Legian Bali, the government issued Government Regulation in Lieu of Law (Perppu) Number 1 of 2002 concerning Eradication of Criminal Acts of Terrorism and Perppu Number 2 of 2002 concerning Enforcement of Government Regulations in Lieu of Law of the Republic of Indonesia. Indonesia Number 1 of 2002 concerning Enforcement for the Bali Bombing Perpetrators October 12, 2002.

Regulation is a strategic policy in eradicating criminal acts of terrorism to strengthen public order and safety of the community while

23 A. Masyhur Effendi, Perkembangan Dimensi Hak Asasi Manusia (HAM) \& Proses Dinamika Penyusunan Hukum Hak Asasi Manusia (HAKHAM), First Printing, Ghalia Indonesia, Bogor, 2005, page. 206. 
still upholding the law and human rights, not being discriminatory, whether based on ethnicity, religion, race or between groups. The Government Regulation in Lieu of Act No. 1 of 2002 was later stipulated as Act No. 15 of 2003.

It can be stated that the government's policy for tackling criminal acts of terrorism, by taking juridical steps, begins with the issuance of:

a. Government Regulation in Lieu of Act No. 1 of 2002, dated October 18, 2002;

b. Government Regulation dated October 18, 2002, in lieu of Act No. 2 of 2002 concerning the Enforcement of Government Regulation in Lieu of Act No. 1 of 2002 concerning Eradication of Criminal Acts of Terrorism, in the Bali Bombing Incident of October 12, 2002;

C. Presidential Instruction Number 4 of 2002 concerning Handling the Problem of Terrorism, October 22, 2002;

d. Presidential Instruction Number 5 of 2002 to the Head of the State Intelligence Agency regarding the Handling of Terrorism Problems, dated October 22, 2002;

e. Act No. 15 of 2003 concerning Stipulation of the Government in Lieu of Act No. 1 of 2000 concerning Eradication of Criminal Acts of Terrorism into Law, April 4, 2003;

f. Act No. 16 of 2003 concerning the Stipulation of Government Regulation in Lieu of Act No. 2 of 2003 concerning the Enforcement of Government Regulation in Lieu of Act No. 1 of 2003 concerning Eradication of Criminal Acts of Terrorism, in the Bali bombing incident on October 12, 2002, April 4, 2003.

Considering the statutory regulations of Act No. 15 of 2003 as well as the legal spirit contained in it, the recognition of terror is not only contrary to the spirit of the Preamble to the 1945 Constitution of the Republic of Indonesia, it is also a heinous, brutal, irresponsible act. With an increasingly widespread network, cooperation between countries is a necessity. In fact, to strengthen the spirit of the law, a more explicit sentence can be added, for example "that terrorism is a barbaric act that is against the conscience of mankind, therefore it must be eradicated together, and at the same time look for the source of its causes and so on and so on".

Currently, criminal acts of terrorism in Indonesia are regulated in Act No. 15 of 2003. Act No. 15 of 2003 was originally a Government Regulation in Lieu of Law (Perppu) Number 1 of 2002, which was later replaced by Act No. 15 of 2003. 2003 was enacted into law. However, at the implementation level, the formulation of the provisions in the Antiterrorism Law is far from perfect so that it becomes an obstacle in eradicating terrorism. This is because, among other things, there are multiple interpretations of the definition of terrorism and terrorists; ineffective coordination between law enforcement agencies. ${ }^{24}$

24 Shanti Dwi Kartika, Politik Hukum Pemberantasan Terorisme, Jurnal Info Singkat Puslit BKD, Vol. X, No. 10 II Puslit May 2018, page.1-6 
Act No. 15 of 2003 (Perppu Number 1 of 2002) also specifically contains provisions regarding the scope of jurisdictions that are transnational and international in nature and contains special provisions for terrorism crimes related to international terrorism activities. This special provision is not a form of discriminatory treatment but is a government commitment to realize the provisions of Article 3 of the Convention Against Terrorist Bombing (1997) and the Convention on the Suppression of Financing Terrorism (1999).

The specifics of Act No. 15 of 2003 as stated in the Elucidation of Act No. 15 of 2003 (Perppu Number 1 of 2002), among others are as follows:

a. This Government Regulation in Lieu of Law is an umbrella provision for other laws and regulations relating to the eradication of criminal acts of terrorism

b. This Government Regulation in Lieu of Law is a special provision that is reinforced by criminal sanctions and is at the same time a coordinating act of Government Regulation in lieu of law (coordinating act) and has the function of strengthening the provisions in other laws and regulations relating to eradication of criminal acts of terrorism;

c. This Government Regulation in Lieu of Law contains special provisions regarding the protection of the human rights of suspects/defendant which are called "safe guarding rules". These provisions include introducing a new legal institution in criminal procedural law called "hearing" and functioning as an institution that conducts "legal audits" of all documents or intelligence reports submitted by investigators to determine whether or not an investigation is continued or not suspicion of acts of terrorism;

d. In this Government Regulation in Lieu of Law it is emphasized that the crime of terrorism is excluded from political crimes or criminal acts with political motives or criminal acts with political aims so that its eradication in bilateral and multilateral cooperation can be carried out more effectively;

e. The Government Regulation in Lieu of Law contains provisions that allow the president to form an anti-terror task force. The existence of the unit is based on the principles of transparency and public accountability (sunshine principle) and/or the principle of limiting the effective time (sunset principle) so that the possibility of abuse of authority possessed by the unit in question can be avoided immediately;

f. This Government Regulation in Lieu of Law contains provisions concerning jurisdiction based on the territorial principle, extraterritorial principle, and active national principle so that it is expected to have effective coverage of criminal acts of terrorism as referred to in the Government Regulation in Lieu of Law. This law extends beyond the territorial boundaries of the Republic of Indonesia. To 
strengthen this jurisdiction, this Government Regulation in Lieu of Law also contains provisions regarding international cooperation;

g. This Government Regulation in Lieu of Law contains provisions regarding funding for terrorist activities as a criminal act of terrorism so as to strengthen Act No. 15 of 2002 concerning the Crime of Money Laundering;

h. 8. The provisions in this Government Regulation in Lieu of Law do not apply to the freedom to express opinions in public, either through demonstrations, protests, or advocacy activities. If in freedom of expression there is an action that contains a criminal element, then the Criminal Code and provisions of laws and regulations outside the Criminal Code will be enforced;

i. In this Government Regulation in Lieu of Law, the threat of criminal sanctions with a special minimum is maintained to strengthen the deterrent function against perpetrators of criminal acts of terrorism.

The use of Act No. 15 of 2003 to regulate the eradication of criminal acts of terrorism is based on the consideration that the occurrence of terrorism in various places has caused material and immaterial losses and caused insecurity for the community.

As stated that in the context of eradicating criminal acts of terrorism, in Indonesia there are regulations for handling and overcoming criminal acts of terrorism, namely Act No. 15 of 2003 concerning Stipulation of Regulations in Lieu of Act No. 1 of 2002 concerning Eradication of Criminal Acts of Terrorism into Laws.

Act No. 15 of 2003 as the basis or legal umbrella that is coordinating which functions to strengthen the provisions in other laws and regulations relating to the eradication of criminal acts of terrorism.

With this law, terrorist threats and attacks, both international in nature and local or national terrorism activities that contain international aspects, can also prevent foreign parties from intervening on the grounds of fighting international terrorism. ${ }^{25}$

The impact of terrorism is enormous, especially in terms of the mass killing of innocent people. Realizing the magnitude of the loss caused by an act of terrorism, as well as the impact that is felt directly by the state, it is the government's obligation to immediately investigate the criminal act of terrorism by punishing the perpetrators and intellectual actors behind the incident. This is a top priority in law enforcement. To carry out the investigation, it is necessary to have legal instruments that regulate terrorism crimes.

Realizing this and being based more on the current regulations, namely the Criminal Code (KUHP) has not specifically regulated and is not sufficient to eradicate terrorism.

The Government of Indonesia feels the need to enact a Law on the Eradication of Criminal Acts of Terrorism, namely by drafting a

25 Romli Atmasasmita, Kapita Selekta Hukum Pidana Internasional, Utomo, Bandung, 2004, page. 87. 
Government Regulation in Lieu of Law (Perppu) Number 1 of 2002, which on April 4, 2003 was ratified as Act No. 15 of 2003 concerning Eradication of Acts of Terrorism. Terrorism Crime. The existence of the Law on the Eradication of Criminal Acts of Terrorism in addition to the Criminal Code and Act No. 8 of 1981 concerning the Criminal Procedure Code (KUHAP), is a special criminal law. This is indeed possible, given that special criminal law provisions can be created because:

a. There is a criminalization process for a certain act in society. Due to the influence of the times, there has been a change of opinion in society. Something that was initially considered not a crime, due to changes in views and norms in society, becomes a criminal act and is regulated in a criminal law legislation;

b. The existing laws are considered inadequate for changes in norms and technological developments in a society, while changes to existing laws are considered to take a lot of time;

c. An urgent situation that is deemed necessary to create a special regulation to deal with it immediately;

d. There is a special act where if the process regulated in the existing laws and regulations is used, it will be difficult to prove it.

As a special law, it means that Act No. 15 of 2003 regulates both materially and formally at the same time, so that there are exceptions to the principles that are generally regulated in the Criminal Code (KUHP)/Book of the Criminal Procedure Code (KUHAP) "lex specialis derogat lex generalis".

The crime of terrorism is one form of crime with an international dimension that is very frightening to the public. In various countries in the world there have been crimes of terrorism, both in developed and developing countries, the acts of terror that have been carried out have taken victims indiscriminately. This caused the United Nations at its congress in Vienna Austria in 2000 to raise the theme The Prevention of Crime and The Treatment of Offenders, among others, to mention terrorism as a development of acts of violence that need attention. According to Muladi, terrorism is an extraordinary crime which also requires handling by utilizing extraordinary means (Extraordinary Measure). ${ }^{26}$

The United Nations (UN) has long paid attention to the problem of terrorism. This attention can be seen from the efforts he has made in an integrated manner, both through legal and political efforts. Through legal efforts, the United Nations has produced a number of conventions related to terrorism issues, including the following:

a. Convention on Offences and Certain Other Acts Committed on Board Aircraft. Signed in Tokyo on 14 September 1963 and entered into force on 4 December 1969;

26 Muladi, Penanggulangan Terorisme Sebagai Tindak Pidana Khusus, Bahan Seminar Pengamanan Terorisme Sebagai Tindak Pidana Khusus, Jakarta, 28 January 2004, page. 1 
b. Convention for the Suppression of Unlawful Seizure of Aircraft. Signed in the Hague on 16 December 1970 and entered into force on 14 October 1971;

c. Convention for the Suppression of Unlawful Acts Against the Safety of Civil Aviation. Signed at Montreal September 23, 1971 and entered into force January 26, 1973;

d. Convention on the Prevention and Punishment of Crimes Against Internationally Protected Persons, Including Diplomatic Agents. Adopted by the General Assembly by Resolution 3166 (XXVIII) of 14 December 1973 and entered into force on 20 February 1977;

e. International Convention Against the Taking of Hostages. Adopted by the General Assembly by Resolution 34/46 of 17 December 1979 and entered into force on 3 June 1983;

f. Convention on the Physical Protection of Nuclear Materials. Signed in Vienna and New York on 3 March 1980. Agreed in Vienna 26 October 1979 and entered into force 8 February 1987;

g. The Protocol for the Suppression of Unlawful Acts of Violence at Air ports Serving International Civil Aviation. Addendum to the Convention for the Suppression of Unlawful Acts Against the Safety of Civil Aviation. Signed in Montreal on 24 February 1988 and entered into force 6 August 1989;

h. Convention for the Suppression of Unlawful Acts Against the Safety of Maritime Navigation. Admitted in Rome on March 10, 1988 and entered into force March 1, 1992;

i. Protocol for the Suppression of Unlawful Acts Against the Safety of Fixed Platform Located on the Continental Shelf. Admitted in Rome on March 10, 1988 and entered into force March 1, 1992;

j. Convention on the Marking of Plastic Explosives for the Purpose of Detection. Created at Montreal on March 1, 1991 and entered into force on June 21, 1998;

k. International Convention for the Suppression of Terrorist Bombing. Adopted by the General Assembly by Resolution 52/164 of 15 December 1997 and entered into force on 23 May 2001;

I. International Convention on the Suppression of Financing of Terrorism. Adopted by the General Assembly by Resolution 54/109 of 9 December 1999 and entered into force on 10 April 2002.

Eradication of criminal acts of terrorism should be included in special laws and regulations because terrorism is an extraordinary crime in the form of cross-border networks such as the people involved, and financial support from outside the country. Along with the development of technology and information, the terrorism movement recruiting new members to become terrorists must always be watched out for. It is 
necessary to involve the international community so that the efforts made can be detected in other parts of the world. ${ }^{27}$

\section{CONCLUSION}

The Legal Politics eradication of criminal acts of terrorism in Indonesia is a proactive policy and anticipatory step that is based on prudence and is long-term in nature. The use of Act No. 15 of 2003 to regulate the eradication of criminal acts of terrorism is based on the consideration that the occurrence of terrorism in various places has caused material and immaterial losses and caused insecurity for the community. It can be stated that the government's policy in tackling criminal acts of terrorism is by taking juridical steps, starting with the issuance of: (1) Government Regulation in Lieu of Act No. 1 of 2002, (2) Government Regulation in Lieu of Act No. 2 of 2002 concerning Enactment of Government Regulation in Lieu of Act No. 1 of 2002 concerning Eradication of Criminal Acts of Terrorism, (3) Presidential Instruction Number 4 of 2002 concerning Handling of Terrorism Problems, (4) Presidential Instruction Number 5 of 2002 to the Head of the State Intelligence Agency regarding Handling Terrorism Issues, (5) Act No. 15 of 2003 concerning Stipulation of the Government in Lieu of Act No. 1 of 2000 concerning Eradication of Criminal Acts of Terrorism into Law, April 4, 2003, (6) Act No. 16 of 2000 2003 concerning Stipulation of Government Regulation in Lieu of Act No. 2 of 2003 concerning Enforcement of Government Regulation In lieu of Act No. 1 of 2003 concerning the Eradication of Criminal Acts of Terrorism.

\section{Books :}

\section{BIBLIOGRAPHY}

A. Masyhur Effendi, 2005, Perkembangan Dimensi Hak Asasi Manusia (HAM) \& Proses Dinamika Penyusunan Hukum Hak Asasi Manusia (HAKHAM), First Printing, Ghalia Indonesia, Bogor;

Abdul Wahid, 2004, Kejahatan Terorisme Prespektif Agama, HAM \& Hukum, Refika Aditama, Bandung;

Agus SB, Darurat Terorisme, 2014, Kebijakan Pencegahan, Perlindungan \& Deradikalisasi, First Printing, Daulat Press, Jakarta;

Loebby Loqman, 1990, Analisis Hukum \& Perundang-Undangan Kejahatan Terhadap Keamanan Negara di Indonesia, Universitas Indonesia, Jakarta;

Moh. Mahfud MD, 2010, Politik Hukum di Indonesia, Third Printing, Revision Edition, Raja Grafindo Persada, Jakarta;

27 Maulana Rahmat, Politik Hukum Terhadap Tindak Pidana Terorisme Dalam Pembaharuan Hukum Pidana Indonesia, Jurnal Wawasan Yuridika, Vol. 1 No. 2 September 2017, page.155-173 
Muhammad A.S. Hikam, 2016, Deradikalisasi: Peran Masyarakat Sipil Indonesia Membendung Radikalisme, PT Kompas Media Nusantara, Jakarta;

Muchamad Ali Syafaat, 2003, Terorisme, Definisi, Aksi \& Regulasi, Imparsial, Jakarta;

Mukti Fajar, Yulianto Achmad, 2010, Dualisme Penelitian Hukum Normatif \& Empiris, Pustaka Pelajar,Yogyakarta;

Romli Atmasasmita, 2004, Kapita Selekta Hukum Pidana Internasional, Utomo, Bandung;

Romi libriyanto, 2013, IImu Negara Suatu Pengantar, Arus timur, Makassar;

Soeharto, 2007, Perlindungan Hak Tersangka, Terdakwa \& Korban Dalam Tindak Pidana Terorisme, Refika Aditama, Bandung;

Simela Victor Mohamad, 2002, Terorisme \& Tata Dunia Baru, Pusat Pengkajian \& Pelayanan Informasi, Sekretariat Jendral DPR-RI, Jakarta;

Susilo Bambang Yudhoyono, 2002, Selamatkan Negeri Kita Dari Terorisme, Kementrian Koordinator Polkam, Jakarta;

Zaenai Asyhadie \& Arief Rahman, 2013, Pengantar Ilmu Hukum, Raja Grafindo Persada, Jakarta;

\section{Journals :}

Derita Prapti Rahayu, Aktualisasi Pancasila Sebagai Landasan Politik Hukum Indonesia, Yustisia, Vol. 4 No. 1 January-April 2015;

Eska Nia Sarinastiti \& Nabilla Kusuma Vardhani, Internet \& Terorisme: Menguatnya Aksi Global Cyber-Terrorism Melalui New Media, Jurnal Gama Societa, Vol. 1 No. 1, January 2018;

Maulana Rahmat, Politik Hukum Terhadap Tindak Pidana Terorisme Dalam Pembaharuan Hukum Pidana Indonesia, Jurnal Wawasan Yuridika, Vol. 1 No. 2 September 2017;

Muladi, Hakekat Terorisme \& Beberapa Prinsip Pengaturan dalam Kriminalisasi, Jurnal Kriminologi Indonesia FISIP UI, Vol II No. 03 December 2002;

Muladi, Penanggulangan Terorisme Sebagai Tindak Pidana Khusus, Bahan Seminar Pengamanan Terorisme Sebagai Tindak Pidana Khusus, Jakarta, 28 January 2004;

Rifki Efendy, Kedudukan \& Kewenangan Tentara Nasional Indonesia Dalam Pemberantasan Terorisme Di Indonesia, Lex Crimen, Vol. III/No. 1/Jan-Mar/2014;

Shanti Dwi Kartika, Politik Hukum Pemberantasan Terorisme, Jurnal Info Singkat Puslit BKD, Vol. X, No. 10/II/Puslit/May/2018;

Syahriza Alkohir Anggoro, Politik Hukum: Mencari Sejumlah Penjelasan, Jurnal Cakrawala Hukum, Volume 10 No. 1 June 2019. 